Rev. Krzysztof Mielnik

Katolicki Uniwersytet Lubelski Jana Pawła II

\title{
God as a source of the power of blessing. The biblical bases and meaning in priesthood's ministry
}

The Latin term benedicere means "to speak about someone good, to praise, to thank, to wish somebody's well, to greet, to call upon the kindness of man and God". The blessing is related to the gifts of God which He gives to a human. The Creator in Adam and Eve delivers His blessing to all human mankind. It is a blessing of life and fertility. A man can give this God's grace to his descendants. It is seen in the history of Israel where the blessing received by Abraham moves to his descendants. Transmitting the God's blessing starts to be a priestly ministry from the Aaron's and his sons becoming as Old Covenant's priests. Jesus Christ is the One and Only Priest who in perfection realises and passes the blessing. We see it in His teaching and mission. He includes the Apostles in this mission and they continue His work and passing the ministry to successors. God's blessing is being passed in sacraments, especially in Eucharist and Sacrament of Penance and Reconciliation. Blessing as a priestly ministry can be seen during all liturgical year when the priest blesses people and different things and subjects. A priest is a "blessing man" who as a "second Christ" becomes a bridge for human to come to God and by his service brings God to a man.

Key words: God, Jesus, Holy Spirit, blessing, to bless, sacraments, priesthood, priest.

The last visible gesture done on Earth by Jesus Christ was His blessing. The introduction to richness of blessing is the result of showing God's generosity in full light and religious sense of admiration of human as a result of this generosity. The blessing is a gift that concerns 
the life itself and its mystery. It is a gift expressed by word and its mystery. The blessing is a word and a gift at the same time, glorifying and good because the goodness it brings it is not just like a thing or gift. The thing what blessing brings does not belong to the material world but to the world of being and it is not the result of action of a human but the creative power of God. The blessing is the creative and reviving gift $^{1}$. No doubt the blessing is the integral element of human life. It can be talked about in many aspects but the priest's blessing deserves a special attention. Why is it so special?

This article is a reflection on the source of blessing and its meaning in life and ministry of priests and People of God. Firstly, the terminology related to blessing will be explained. Secondly, we will talk about the source of blessing and its meaning in the history of the Chosen Nation and what role it had in the teaching and ministry of Jesus Christ. Then the role of blessing in the life of Church and ministry of priests will be explained.

\section{The meaning of term „blessing”}

If we want to look into the topic of blessing, especially the priest blessing, we need to start from explaining the terminology. The Polish word "to bless" comes from latin word benedicere. The latin benedicto comes from bene - good and dicere - to speak. To bless (benedicere) is to ,speak about someone good, to praise, to thank, to wish somebody's well, to greet, to call upon the kindness of man and God" ". When we look into the Bible we will discover that "blessing" and "benediction" (Hebrew - beraka) in the secular sense only means gift, mutual endowment. In the Old Testament it is referred primarily to the gifts of God. First people were blessed by the Creator. The God's blessing was identified with the gift of life, fertility, welfare and peace. The symbol of this blessing's meaning was a water dropping down from heaven that was giving life to the Earth. In the Old Testament "to bless" meant firstly to greet someone on the street. But most commonly word was related to God who as the giver of life shows grace to people - by blessing them ${ }^{3}$.

J. Guillet, Błogosławieństwo, in: X. Leon-Dufour (ed.), Stownik Teologii Biblijnej, Poznań 1994, p. 79.

2 H. Szkiłądź, Błogosławić, in: Stownik Języka Polskiego, vol. I, p. 168.

3 T. Jaklewicz, Błogostawcie!, "Gość Niedzielny” 02/2013, p. 25. 


\section{Blessing as the source of life and gift from God}

Benediction is the acting of God that gives life, its source is the Father. His blessing is a word and a gift at the same time. In relation to human this terminology will mean adoration and giving oneself to the Creator in thanksgiving (KKK 1078). It has been accompanying man since the beginning of his existence. In the beginning God blesses living creatures, especially man and a woman (KKK 1080). On the first pages of the Bible already, after creating a human, God in Adam and Eve blesses all the humankind: "God created man in the image of himself, in the image of God he created him, male and female he created them. God blessed them, saying to them, 'Be fruitful, multiply, fill the earth and subdue it. Be masters of the fish of the sea, the birds of heaven and all the living creatures that move on earth. God also said, 'Look, to you I give all the seed-bearing plants everywhere on the surface of the earth, and all the trees with seed-bearing fruit; this will be your food. And to all the wild animals, all the birds of heaven and all the living creatures that creep along the ground, I give all the foliage of the plants as their food.> And so it was. God saw all he had made, and indeed it was very good. Evening came and morning came: the sixth day (Genesis 1, 27-31). The one who blesses is God and His blessing always gives life ${ }^{4}$. The oldest blessings relates to the idea of migratory life and refer to the fertility of the Earth, the long life the capacity of transmitting the name to the descendants and having their own land ${ }^{5}$. Those blessing received from the God for human, he can give out to others.

\section{The God's blessing for Abraham and his descendants}

Starting from Abraham, God's blessing goes through the history of people that was going to death - turning it to life, to its source; by the faith of "father of the faithful" who accepts this blessing, the story of salvation has begun (KKK 1080). The God's blessings appears in amazing and saving moments such as the birth of Isaac, coming out of Egypt (Passover and Coming Out), the gift of Promised Land, the choice of David, the presence of God at Temple, purifying exile and return of "small Rest": The Law, The Prophets and Psalms from which the Liturgy of Chosen Nation is made, they all remind about those

J. Guillet, Błogostawieństwo, in: X.Leon-Dufour (ed.), Stownik Teologii Biblijnej, Poznań 1994, p. 80.

5 L. Stachowiak, Błogostawieństwo, in: F. Gryglewicz (ed.), "Encyklopedia Katolicka”, vol. II, Lublin 1995, c. 682. 
Biblical theology
God's blessings and respond to them by worshipping and thanksgiving at the same time (KKK 1081).

It can be seen in Abraham's life and mission whom by his faith and giving his life to God has become the blessing to all the nations of the world. He distinguished himself from other people - his pagan neighbours because he got to know the existence of God - The only One who created the world, whilst the pagans by worshipping different gods remain wrong. We know this reasoning about the ability to know God "from nature" also from the deuterocanonic Book of Wisdom 13, $1 \mathrm{nn}$ and Romans 1, 18-23. Courage in spiritual struggles with pagan world was awarded. God appeared to Abraham and called him to fulfil sublime mission. On the way of resigning from what he had, Abram was to achieve a lot more: „Yahweh said to Abram, 'Leave your country, your kindred and your father's house for a country which I shall show you; and I shall make you a great nation, I shall bless you and make your name famous; you are to be a blessing!" (Gen 12, 1-2). So it is not about a particular calling, in some way egoistic because distinguishing Abram from others but about the act what has got collective dimensions and meaning. Straight after this the theme of blessing was highlighted. The destiny of individual Abram's calling is most widely understood as universalism. The new relationship of Abram and God was sealed by the New Covenant made after fulfilling the purpose of migration - settling down in Kaanan ${ }^{6}$. It is fulfilled in the birth of Izaac who becomes the blessing for Abraham and also a heir of blessing.

In the Book of Genesis we also discover the story about Jacob who fight with God Himself for a blessing. The Patriarch says to God: "I will not let you go unless you bless me." (Genesis 32,27 ). This is an image of spiritual battle showing how precious gift is the God's blessing. In Jewish family the father used to bless the children. Also the surprising situation took place when the "weaker" was blessing the "stronger". It turns out that man can blesses God Himself. He confesses in this way the truth about that he has been gifted and gives his thanksgiving to his Creator. The formula of blessing that is being used the most often in Israel was adjective expression: "Let be...(name) blessed!". This kind of sentence was the exclamation of admiration that God reveals His power and generosity to oneself, in its life. In turn the exclamation: "Let be God blessed" was to show exultation that a human received being a witness of a situation which God's presence was obvious. This both calling shows what is the essence of blessing - the public professing the majesty of God and thanksgiving for His goodness. Along

W. Chrostowski, Pięcioksiag czyli Tora Mojżesza, Warszawa 2007, p. 36-37. 
with the words of blessing - gestures were accompanying them such as putting hands on a head, raising hands or giving some king of material gift ${ }^{7}$. God blessing the people gives them sign of His grace and favour and the people blessing God recognises His presence among them. God blessing the Israel gives him a share in His own life and eternal design and the people blessing Him shows Him gratitude for His goodness and help ${ }^{8}$.

\section{Aaron's blessing}

The blessing is a special action what's purpose is to get God's goodwill for someone or for group of people by the appropriate words or symbolical sacral gestures. They show existential dependance from the Creator. Human gives blessing in the name of God and anyone can do that, however, the special power is connected with the blessing of people authorised to transmit the grace of God. The privilege and responsibility of blessing is associated with the priesthood. The Book of Numbers connects blessing with priests from Aaron's generation who was giving it during celebration of the Old Testament's cult. ${ }^{9}$. They were chosen and destined by God to this function: „God spoke to Moses and said, «Speak to Aaron and his sons and say: «This is how you must bless the Israelites. You will say: May God bless you and keep you. May God let his face shine on you and be gracious to you. May God show you his face and bring you peace.» This is how they must call down my name on the Israelites, and then I shall bless them.> (Numbers 6, 22-27).

The hebrew birkat (ha-)kohanim are the words said by Moses to the high priest Aaron to bless the people. At the time of the Jerusalem Temple, the high priest used to proclaim birkat kohanim every morning, and at the same time it was being said in all the provincies. It was being said four times in Jom Kipur: during szacharit (dawn), musaf (additional prayer after szacharit), minchy (afternoon prayer) i neili (obligatory prayer in Jom Kipur). After the Temple was demolished, Aaron's blessing was being said only during morning prayers in Palestine, and in Jom Kipu - four times, as it was in the Temple. In Babilonia, it was being said in the morning and in the afternoon and

T. Jaklewicz, Błogosławcie!, “Gość Niedzielny” 02/2013, p. 25.

$8 \quad$ P.S. Minear, Btogostawieństwo, w: B. M. Metzger, M. D. Coogan, Stownik wiedzy biblijnej, Warszawa 2004, p. 71, c. 1.

9 L.Stachowiak, Btogostawieństwo, in:F. Gryglewicz(ed.), Encyklopedia Katolicka, t. II, Lublin 1995, c. 682 . 
Biblical theology

in Jom Kipur - three times, leaving it out during minchy. Before proclaiming birkat kohanim, the priest was taking off his shoes and one of the Levites was washing his hands, and then he was going to aron (ha-)kodesz (built niche in the eastern wall of synagogue or wardrobe) and with the face turned to praying people, with the hands raised up (in a special way - fingers spaced two and thumbs side by side), after chaz(z)anem (synagogue intendant), word after word - he was saying the blessing ${ }^{10}$.

\section{Priests as people chosen by God}

The priest in the Old Testament had to do mainly the sacrifice. At that time he was as an intercessor who was dedicating the sacrifices of faithful to God, and to them was passing by the blessing. All the values of the Old Testament take on significance only in the person of Jesus Christ who fills them and infinitely exceeds them. Now the general law of revelation applies in a special way to the case of priesthood ${ }^{11}$. The priesthood of the Old Testament was chosen by God for its special possession, therefore it had no inheritance on the Earth but was called to serve God: „, Of the Israelites, I myself have chosen your brothers the Levites as a gift to you. As men dedicated, they will belong to God, to serve at the Tent of Meeting. You and your sons will undertake the priestly duties in all that concerns the altar and all that lies behind the curtain. You will perform the liturgy, the duties of which I entrust to your priesthood. But an unauthorised person approaching will incur death,” (Numbers 18, 6-7), „God said to Aaron: 'You will have no heritage in their country, you will not have a portion like them; I shall be your portion and your heritage among the Israelites. <Look, as heritage I give the Levites all the tithes collected in Israel, in return for their services, for the ministry they render in the Tent of Meeting. The Israelites will no longer approach the Tent of Meeting, on pain of committing a deadly sin. Levi will discharge the duties of the Tent of Meeting, and the Levites will bear the consequences of their own guilt. This is a perpetual decree binding all your descendants: the Levites will have no heritage among the Israelites, for the tithe which the Israelites set aside for God is the heritage I have given the Levites. This is why I have told them that they will have no heritage among

$10 \quad$ M. Bendowska, Żydowski Instytut Historyczny, http://www.jhi.pl/psj/Blogoslawienstwo_kaplanskie, [16.10.2017].

11 A. George, Kapłaństwo, in: X. Leon-Dufour (ed.), Stownik Teologii Biblijnej, Poznań 1994, p. 362. 
the Israelites." (Numbers 18, 20-24). In the Book of Isaiah we can find the term signifying a man called by God to a special assignment in the history of salvation. Hebrew term bechir (chosen) relates to one of the Biblical theology most important dimensions of life of Israel, the chosenness. It seems that the only motive for God to choose His servants is love. The one whom God has chosen gets always His help. The choice is always connected with the giving of the Spirit. Only having the Spirit of Yahweh the chosen of God can effectively fulfil the tasks entrusted to them. The action of the Spirit of Yahweh appears in an extraordinary way in the expected and perfect king. The Messiah is to be given the Spirit of Yahweh ${ }^{12}$.

\section{Jesus Christ as a source of blessing}

Catechism of the Catholic Church indicates the role of Jesus in the work of salvation. The Father as a Source and Destination of all the blessings, in His Word what took the human body for us, died and resurrected, fulfils us with His blessings and because of them pours in our hearts a Gift that contains all the gifts of the Holy Spirit (KKK 1082). When the name of God is spoken upon the people, the God's blessing is brought upon them. The New Testament confirms this truth. Jesus Christ - God-Human became the most perfect, fullest blessing not only for the Jews but for all the people, for all the Earth and world. God blessed everybody in Him. Jesus is the „,blessed fruit” of „the blessed womb” of Mary ${ }^{13}$.

Jesus appears as a human who has the fullness of the Spirit of God in the moment of christening in the Jordan river. John the Baptist gives his testimony about it and states that he saw a Holy Spirit descending and remaining on Jesus. And in the last sentence of his testimony he solemnly announces: ", I have seen and I testify that he is the Chosen One of God" ( $J$ 1,34). Jesus wants to reach to every person with His mission of salvation ${ }^{14}$. Starting His mission Jesus goes to the people, bringing them the blessing. It can be seen in His preaching, especially on ,the Sermon on the Mount”.

\footnotetext{
12 H. Witczyk, Błogosławieństwo wiary, Kielce 2015, p. 80-90.

13 T. Jaklewicz, Błogosławcie!, “Gość Niedzielny” 02/2013, p. 24.

H. Witczyk, Błogosławieństwo wiary, Kielce 2015, p. 99-100.
} 


\section{Blessing in teaching and ministry of Jesus}

Blessings are in the centre of Jesus's teaching. Its proclaiming takes promises given to the Chosen Nation from the Times of Abraham. Jesus fulfils them, pointing out its mediation not only for the use of earthly goods but for the Kingdom of Heaven: „How blessed are the poor in spirit: the kingdom of Heaven is theirs. Blessed are the gentle: they shall have the earth as inheritance. Blessed are those who mourn: they shall be comforted. Blessed are those who hunger and thirst for uprightness: they shall have their fill. Blessed are the merciful: they shall have mercy shown them. Blessed are the pure in heart: they shall see God. Blessed are the peacemakers: they shall be recognised as children of God. Blessed are those who are persecuted in the cause of uprightness: the kingdom of Heaven is theirs. 'Blessed are you when people abuse you and persecute you and speak all kinds of calumny against you falsely on my account. Rejoice and be glad, for your reward will be great in heaven; this is how they persecuted the prophets before you."(Mt 5, 3-12) (KKK 1716).

On the "Sormon on the Mount" Jesus gives the eschatological blessing to people of certain features or acting in a certain way. The Blessing assures that God will stand by them and reward them at the time of salvation, the final kingship of God. He strengthens them when they face difficulties in this way ${ }^{15}$. All blessings promise future salvation, the perfect Kingdom of God, what is promised right now and to which we can be „written in heaven”. Jesus in the Gospel does not call blessed the state of perfection or fulfilment but the man who strives for Him, who is in the path between vocation and to manifest being perfect ${ }^{16}$.

The words "to bless" and "blessing" are written in the Bible 410 times. According to the original they mean „happy”, like for example in „the Surmon on the Mount” (Mt 5, 1-12). However, the word "blessed” translate as „happy” is not that accurate. In Greek language the word makarios has been used which shows the state where everything goes according to the plan or it symbolises those for whom everything goes really well. We could say that a „blessed" man is a man who no matter what situation he is in - he is always happy, everything goes well for him. Those ones who the Gospel's blessings speak about are not blessed because of the situation they are in but because of Jesus. They hope because the Kingdom of Heaven is also for them. People do not

15 P. J. Achtemeier, Błogosławieństwa, in: P. J. Achtemeier (ed.), Encyklopedia biblijna, Warszawa 2004, p. 130, c. 2.

16 A. Grabner-Haider, Błogostawieństwa, in: A. Grabner-Haider (ed.), Praktyczny słownik biblijny, Warszawa 1994, c. 118. 
receive the blessing only because they are poor in spirit, persecuted, etc. Not the only state of them counts but the fact they are not separated from God. The circumstances of life that Jesus calls blessed are Biblical theology generally considered as everything but no blessing. Jesus shows us that also in these situations people are blessed because the God exists. ${ }^{17}$.

Blessings reflects the face of Jesus Christ and describe His love. They express the vocation of the faithful included in the glory of His Passion and Resurrection, also explain the characteristic actions and attitude of Christian life. They are paradoxical promises that support hope in hardships, announce the goodness and reward that in hidden way are given to the disciples, and already begun in life of the Blessed Virgin Mary and all the saints. (KKK 1717).

The blessed people are linked in lack and persecution in life on Earth but also for all of them the reward is promised - The Kingdom of Heaven with its supernatural gifts. It is to pay for the practice of virtues and the fulfilment of human desires and aspirations. Blessed are called all those who could live up to the time of Messiah, those over who not only listen to the Word of God but also accomplish them and those faithful to God and guarding, they are awaiting His coming ${ }^{18}$. To become blessed - so to obtain blessing is to participate in supernatural goods that the Kingdom of God carries along and the participation in it by having a relation with the person of Christ. To deserve this blessing not only by the practice of different virtues but most of all by clinging to God with the unwavering faith. Although the promised blessings are of a future, eschatological and spiritual nature, yet in their light, all temporal values also take on a greater significance of gratitude for spiritual goods, and especially for choosing and destining to glory ${ }^{19}$. Blessings shows the sense of human life, the final destination of human actions: God is calling us to His ow happiness. This calling is directed to each person but also to all the Church, the new people of those who accepted the promise and live in it with faith (KKK 1719).

As a real and eternal Priest, Christ was blessing children during His public ministry: „Then he embraced them, laid his hands on them and gave them his blessing." (Mark 10, 16), and was blessing His disciples: „Then he took them out as far as the outskirts of Bethany, and

17 J. Witko, Moc błogosławieństw, "Przewodnik katolicki" 52/2014, s. 56-57.

18 K. Romaniuk, Błogosławieństwa Ewangeliczne, in: F. Gryglewicz (ed.), Encyklopedia Katolicka, vol. II, Lublin 1995, c. 680-681.

19 K.Romaniuk, Btogostawieństwo, in: F. Gryglewicz(red), Encyklopedia Katolicka, vol. II, Lublin 1995, c. 683. 
Biblical theology

raising his hands he blessed them." (Luke 24, 50). In the Book of Acts of Apostles saint Peter explained in one of his speeches that Jesus was sent to the Earth to bless: „It was for you in the first place that God raised up his servant and sent him to bless you as every one of you turns from his wicked ways.)" (Acts of Apostles 3, 26). Christ instructed His disciples to give blessing even for oppression and persecution ${ }^{20}$.

\section{Inclusion of the disciples in Jesus's mission}

Jesus includes into His big mission all the people who believes in Him. In the most important moment of His life, when His hour came, He called disciples to join His mission of salvation, in a way of service. The Apostles after the Resurrection of Christ have full consciousness of that because of an invitation from the Messiah and connection with Him, they are the servants of God. In the unanimous prayer that they bring to God in the midst of the persecution of the Sanhedrin, they say: , And now, Lord, take note of their threats and help your servants to proclaim your message with all fearlessness, by stretching out your hand to heal and to work miracles and marvels through the name of your holy servant Jesus." (Acts of Apostles 4, 29-30). It is hard to get a text which is more unequivocally showing disciples taking part in Jesus's mission ${ }^{21}$.

After His resurrection Christ by giving the Holy Spirit to the Apostles entrusts them His power of blessing: they become sacramental symbols of Christ. By the power of the same Holy Spirit they entrust empowerment to their successors. This apostolic succession forms the structure of the whole liturgical life of the Church. It has a sacral character transmitted by the Sacrament of the Holy Orders (KKK 1087).

The Apostles did not receive only some kind of function that every member of the Church could do but were specially and internally involved in the mission of the Incarnated Word. Apostles did the same when they chose their cooperates who were supposed to be their successors in ministry. This choice was covering also those who were supposed to continue their mission in the history of Church - the mission of representing The Lord Christ and Redeemer ${ }^{22}$. All the Christians are called to take part in the mission of the servant of the Lord. The

20 K.Romaniuk, Błogostawieństwo,in: F. Gryglewicz (ed.), Encyklopedia Katolicka, vol. II, Lublin 1995, c. 683.

H. Witczyk, Błogosławieństwo wiary, Kielce 2015, p. 101-102.

22

Jan Paweł PP. II, List Apostolski Ordinatio Sacerdotalis, w: Breviarium Fidei. Wybór doktrynalnych wypowiedzi Kościoła, Poznań 2007, s. 670. 
bishops, priests and deacons take part in this mission in the first row as people chosen and gifted of the grace of faith and the power of the Holy Spirit. They must reveal the God to people around them ${ }^{23}$.

\section{The liturgy of Church as a symbol of blessing}

This mission can be discovered in the liturgy of Church where in fullness and speciality a man represents God Himself. It can be seen during the liturgical functions where the priest in verbal formula along with the particular gesture or liturgical symbol asks God for sanctification and giving spiritual and material goods for the people of God ${ }^{24}$.

As the Pope Pius XI in his encyclical Ad catholici sacerdotii says, the priest is the servant of Christ, is the instrument in the hand of the Savior to lead His mission further in time what in over Earthly efficiency renewing the humanity, lead it to a noble cult. The priest is a "second Christ" according to the Gospel's words: ,, and he said to them again, 'Peace be with you. 'As the Father sent me, so am I sending you." ( $J$ $20,21)$. The power entrusted to a priest based on a Sacrament of Holy Orders is permanent and lasting ${ }^{25}$.

God gives the power of His blessing to those who substitutes Him on Earth - the priests. They always bless in His name, in the name of the Father, the Son and the Holy Spirit. Blessing is not a magic, it is a grace given most often during sacraments where the priest in the name of God blesses a man ${ }^{26}$. It can be seen very clearly in the liturgy of Church what has double dimension. It is understood as an answer of faith and love for the "spiritual blessings" we receive from the Father. On one hand the Church united with its Lord and in „Holy Spirit” (Luke 10, 21), blessed the Father , Thanks be to God for his gift that is beyond all telling!" (2 Kor 9,15$)$ by the adoration, worship and thanksgiving. On the other hand up to fulfilment of God's plan the Church does not stop giving to the Father ,sacrifices from received from Him gifts" and ask Him to send the Holy Spirit upon those gifts, oneself, on all the faithful and upon the whole world and to bring the fruits of life by the

$23 \quad$ H. Witczyk, Błogosławieństwo wiary, Kielce 2015, p. 104.

24 Por.W.Schenk, Btogostawieństwo, in: F. Gryglewicz (ed.), Encyklopedia Katolicka, vol. II, Lublin 1995, c. 684.

25 Pius PP. XI, Litterae encyclicae Ad catholici sacerdotii, 20.12.1935, AAS 28 (1936), p. 5-53, tekst polski: "Wiadomości Archidiecezjalne Warszawskie" 26 (1936) nr 1, p. 1-32.

26 Btogosławieństwo, in: D. Szczerba, Praktyczny Leksykon Modlitwy, Kraków 2007, p. 21. 
communion in death and resurrection of Christ the Priest and by the power of blessing ,to the praise of the glory of his grace, his free gift to us in the Beloved," (Ef 1, 6) (KKK 1083). In the liturgy the Church blesses and worships God the Father as a source of all the blessings of creation and salvation that He blessed us in His Son to give us the Spirit of the children of God (KKK 1110).

\section{Eucharist and sacrament of penance and reconciliation}

The power of blessing of the priest can be fully seen in sacraments, especially in Eucharist and Sacrament of Penance and Reconciliation. Jesus Christ established a sacrament of Eucharist and consequently decided to establish a sacrament of Holy Orders. He could only entrust the Eucharist to chosen people's hands. This is how the Church was born and this i show the Church understands the union between the priesthood and Eucharist. The Highest and the Only One Priest is Jesus Christ. He is a Good Shepherd. The priest has participation in the greatest power existing in the world. Priest touching a heart frees it from guilt, from the greatest misfortune that can happen to a human - that is sin. The priest can sanctify things and people also when he is a sinful himself because he is doing it by the power of God, not his ${ }^{27}$. The blessings occur at the beginning and the end of the Holy Mass, there are like frames in the blessing-thanksgiving nature of the Mass. Preparation of sacrificial gifts of bread and wine has also a character of blessing: „Blessed are you Lord, the God of universe...” (MR 1970 r.). The blessing is also a formula said before the reading of the Gospel "The Lord is with you", in the beginning of the eucharistic prayer and before final blessing and also words ,The peace of the Lord be with you always, along with the sign of peace. Many forms and formulas of the blessing, especially the formulas of greeting given by Saint Paul the Apostole in liturgical form already: „The grace of the Lord Jesus Christ, the love of God and the fellowship of the Holy Spirit be with you all!" (2 Kor 13,13), went to eastern and western liturgy, and in Roman Missal some of them became a form of greeting ${ }^{28}$.

During the Eucharist priest says for couple of times "The Lord be with you". What does it mean? Jesus is with His people in all their life experiences and situations. The God says: „I shall not fail you or

$27 \quad$ E. Staniek, Uwierzyć w Kościót, http://mateusz.pl/ksiazki/es-uwk/es-uwk ii 05.htm, [16.10.2017].

28 Por. W.Schenk, Błogosławieństwo,in: F. Gryglewicz(ed.),Encyklopedia Katolicka, vol. II, Lublin 1995, c. 684. 
desert you,” (Hebrews 13, 5). And in Gospel Jesus ensures: „I am with you always; yes, to the end of time." (Mt 28, 20). The Lord is with $\mathrm{h} / \mathrm{is}$ faithful not only when it is good but also and maybe primarily when it is badly. God reminds about this through a priest. And words ,The Lord is with you" are for the people source of faithful blessing. At the end of the Mass the priest gives in a sign of a cross - a blessing which is done in the name of Almighty God. It has a huge meaning. People go with this blessing home and the Lord is going with them. Everything from that moment can be different, under the condition that we will take this blessing with faith and bringing it in life. ${ }^{29}$. There are many different blessings existing in Church, with the official liturgical character. It is usually accompanied by the spirkling with the Holy Water and that is why it is said very popularly about sanctifying people or things. Priest do that generally. The special two-volume book of blessing exist that relates to different situations in life. ${ }^{30}$.

\section{Forms and methods of blessings}

Among the sacramentals we can find firstly the blessings of people, meals, things, places. Each blessing is God's worshipping and prayer for His gifts. Christians in Christ are „Blessed be God the Father of our Lord Jesus Christ, who has blessed us with all the spiritual blessings of heaven in Christ." (Ephesians 1,3). And this is why the Church gives blessing calling the name of Jesus and usually doing the holy sign of the cross (KKK 1671).

There are many other forms of blessings in Church apart from blessings during Eucharist. We can highlight blessings of people, meals, things, places but most primarily we get our attention to blessing of the Blessed Sacrament. This form rose in late medieval as a numerous manifestation of increased eucharistic worship. This blessing took place at the end of service or teoforic processions and was ministered as a sign of the cross. The special form of blessing is related to realisation of life vocation, for example blessing in episcopal ordination, Holy Orders of the Presbyterian, ordination of the diaconate and religious profession. The gesture accompanying the blessing is taking the hands out completed with the prayer. The blessing is connected with ministering of sacraments. Blessing in Christening sacrament is related to blessing parents and the child and participants, during Sacrament of Confirmation - the blessing of Bishop to newly confirmed,

29 J. Witko, Moc błogosławieństw, "Przewodnik katolicki” 52/2014, p.

T. Jaklewicz, Błogosławcie!, “Gość Niedzielny” 02/2013, p. 25. 
during Sacrament of Anointing the Sick - blessing the people taking the sacrament, and during the Sacrament of Marriage - blessing the newlyweds. Moreover, in case of danger of life every priest can minister an apostolic blessing ${ }^{31}$.

Some of the blessings has permanent nature; its result is sacrificing some people to God and reservation of certain objects and places to liturgical use. Among the blessing of people - which cannot be mixed up with sacramental ordination - the blessing of the abbot or priest of the convent, the consecration of the virgin and widows, the ordinance of religious profession and blessing for certain ministries in Church (lectors, acolytes, catechists etc.). As an example of blessing the things we can list sanctifying the church or the alter, blessing of sacred oils, vessels and liturgical vestments, bells, etc. (KKK 1672).

Blessing of the thing is related to the liturgical year. During celebration of different festivities, certain things are being blessed, for example: water for the feast of Epiphany, wax candle called Blessed Candle in the feast of the Presentation of the Lord, ashes at Ash Wednesday, palms on the Palm Sunday, oils on Holy Thursday, food on Holy Saturday, fire, paschal and baptismal water on the Easter Vigil ${ }^{32}$. The blessing can be expressed in two forms: firstly the prayer in the Holy Spirit goes through Christ to the Father (we bless Him because He blessed us) (por. Ephesians 1, 3-14; 2 Kor 1, 3-7; 1 P 1, 3-9.), then beggs for a grace of Holy Spirit who through Christ goes to the Father (this is Him who blesses us, por. 2 Kor 13,13; Rz 15, 5-6. 13; Ef 6, 23-24) (KKK 2627).

\section{Priest as a person of blessing}

For sure the blessing is coming through most powerfully through sacraments. Nevertheless, the wise, warm, fervent word of blessing has great power. Priest by its definition is a man who blesses, and this is what he needs to do. He has influence on the presence of God among the people by his service. The danger is to have a magical approach to blessing, some naive, pagan expectation that it will automatically safeguard human fate. This treating of blessing must be rejected. But the more extreme and dangerous seems to be the second extreme today - the unbelief in God's presence and acting in human life. The

31 Por.W.Schenk, Błogosławieństwo, in:F. Gryglewicz(ed.),Encyklopedia Katolicka, vol. II, Lublin 1995, c. 685.

32 Por.W.Schenk, Błogosławieństwo, in:F.Gryglewicz(ed.),Encyklopedia Katolicka, vol. II, Lublin 1995, c. 685. 
blessing is an expression of faith that we know that we are not alone, but the God watches over us ${ }^{33}$, that ,as the light and warmth of the sun is a blessing to the Earth, so the light of God is for mankind when He shines His face upon it" ${ }^{34}$.

The blessing is a given gift to a man by God through priests. But the biggest gift that was given to us by our Creator and sent by Jesus is the Holy Spirit. He is the blessing because He was given to us to have Him and for Him to remain in us. The blessing of God in full meaning is the Holy Spirit ${ }^{35}$. The power of priesthood comes from Him. He is the One sanctifying the Church that watches over the people to go through the road of salvation. Priest as an instrument of God is called to minister God's blessing in the most perfect expression which is the Holy Spirit, in a special and exceptional way in the power of Christ.

The blessing of God that accompanies human always is a sign of the Creator's care about His creation. God as a source and destiny of blessing calls chosen people to deliver His blessing. It can be seen from the very beginning when God blessed the human as a crown of creation. In the history of Israel certain people became transmitters of God's grace. In the moment of shaping the cult this special task was entrusted to priests. The fullest sign of priest's function is realised in Jesus who is a real and eternal Priest. Chosen members of the Church have participation in this priesthood through the ordination. They deliver to the People of God the biggest and greatest gift - the Holy Spirit who is the most perfect sign of God's blessing. God is always a source of priest blessing. Priests bless the faithful in Him name. This is a very important function in priest's ministry because the priest stands in front of people as an alter Christus, becoming a connector between God and people. The blessing is an expression of deep strive of Christian prayer: it is a meeting God and a man; in blessing the gift of God and acceptance by man call each other and unite. The prayer of blessing is man's answer to God's gifts. Because God blesses, the human's heart can bless God who is the source of all blessing (KKK 2626).

33 T. Jaklewicz, Błogosławcie!, “Gość Niedzielny” 02/2013, p. 26.

34 Benedictus PP. XVI, Rozważanie przed modlitwą Anioł Pański. Na drogach dialogu, rozumienia i pojednania, 01.01.2013, „L'Osservatore Romano” wyd. pol. 34 (2013) nr 2, p. 17.

35 J. Guillet,Błogosławieństwo, in:X.Leon-Dufour(ed.), Stownik Teologii Biblijnej, Poznań 1994, p. 85. 


\section{BÓG JAKO ŹRÓDŁO MOCY BŁOGOSŁAWIEŃSTWA. BIBLIJNE PODSTAWY I ZNACZENIE W POSŁUDZE KAPŁAŃSKIEJ}

Łaciński termin benedicere oznacza "mówić o kimś dobrze, życzyć dobra, przyzywać łaskawości człowieka i Boga". Błogosławieństwo odnosi się również do darów Boga, jakie daje On człowiekowi. Stwórca w Adamie i Ewie udziela błogosławieństwa całemu rodzajowi ludzkiemu. Jest to błogosławieństwo życia i płodności. Tę Bożą łaskę człowiek może przekazywać swoim potomkom. Widać to w dziejach Izraela, gdzie błogosławieństwo, które otrzymuje Abraham przechodzi na jego potomków. Od wyboru Aarona i jego synów na kapłanów Starego Przymierza, przekazywanie Bożego błogosławieństwa staje się funkcją kapłańską. Jedynym kapłanem jest Jezus Chrystus, który w sposób doskonały urzeczywistnia i przekazuje błogosławieństwo. Widać to w jego nauczaniu i misji. W tę misję włącza apostołów, którzy kontynuują Jego dzieło i przekazują posługiwanie swoim następcą. Boże błogosławieństwo przekazywane jest w sakramentach, szczególnie w Eucharystii oraz sakramencie pokuty i pojednania. Funkcję kapłańską, jaką jest błogosławienie, widać w trakcie całego roku liturgicznego, kiedy kapłan błogosławi ludzi i różne przedmioty. Kapłan to człowiek błogosławiący, który jako „drugi Chrystus" staje się pomostem dla człowieka w dotarciu do Boga i jednocześnie swoją posługą przybliża Boga człowiekowi.

Słowa kluczowe: Bóg, Jezus, Duch Święty, błogosławieństwo, błogosławić, sakramenty, kapłaństwo, kapłan.

\section{Bibliography:}

1. Pismo Święte Starego i Nowego Testamentu, wydanie piąte, Pallottinum Poznań 2000.

2. Katechizm Kościoła Katolickiego, Wydanie II, Pallottinum Poznań 2012.

3. Achtemeier P. J., Błogostawieństwa, in: P. J. Achtemeier (ed.), Encyklopedia biblijna, „Vocatio" Warszawa 2004.

4. Bendowska M., Żydowski Instytut Historyczny, http://www.jhi.pl/psj/ Blogoslawienstwo_kaplanskie (16.10.2017).

5. Benedictus PP. XVĪ, Rozważanie przed modlitwą Anioł Pański. Na drogach dialogu, rozumienia i pojednania, 1.1.2013, „L'Osservatore Romano” wyd. Pol. 34(2013) nr 2.

6. Chrostowski W., Pięcioksiag czyli Tora Mojżesza, Skrypt dla studentów II roku teologii ogólnej i turystyki krajów biblijnych WT UKSW, Warszawa 2007.

7. George A., Kaptaństwo, in: X. Leon-Dufour (red.), Stownik Teologii Biblijnej, Pallottinum Poznań 1994.

8. Grabner-Haider A., Błogostawieństwa, in: A. Grabner-Haider (ed.), Praktyczny stownik biblijny, PAX Warszawa 1994. 
9. Guillet J., Btogosławieństwo, in: X. Leon-Dufour (red.), Stownik Teologii Biblijnej, Pallottinum Poznań 1994.

10. Jaklewicz T., Błogostawcie!, “Gość Niedzielny” 02/2013.

Biblical theology

11. Jan Paweł PP. II, List Apostolski Ordinatio Sacerdotalis, in: Breviarium Fidei. Wybór doktrynalnych wypowiedzi Kościoła, Księgarnia św. Wojciecha Poznań 2007.

12. Minear P. S., Btogostawieństwo, in: B. M. Metzger, M. D. Coogan, Stownik wiedzy biblijnej, „Vocatio” Warszawa 2004.

13. Pius PP. XI, Litterae encyclicae Ad catholici sacerdotii, 20.12.1935, AAS 28 (1936), pp. 5-53, tekst polski: „Wiadomości Archidiecezjalne Warszawskie” 26 (1936) $\mathrm{nr} 1$.

14. Romaniuk K., Błogosławieństwa Ewangeliczne, in: F. Gryglewicz (red.), Encyklopedia Katolicka, vol. II, Towarzystwo Naukowe KUL Lublin 1995.

15. Schenk W., Błogosławieństwo, in: F. Gryglewicz (ed.), Encyklopedia Katolicka, vol. II, Towarzystwo Naukowe KUL, Lublin 1995.

16. Stachowiak L., Błogostawieństwo, in: F. Gryglewicz (ed.), Encyklopedia Katolicka, vol. II, Towarzystwo Naukowe KUL, Lublin 1995.

17. Staniek E., Uwierzyć w Kościót, http://mateusz.pl/ksiazki/es-uwk/esuwk ii 05.htm, 16.10.2017.

18. Szkiłą̧ź H., Błogostawić, Słownik Języka Polskiego, vol. I, PWN Warszawa 1995.

19. Szczerba D., Praktyczny Leksykon Modlitwy, Wydawnictwo M, Kraków 2007.

20. Witczyk H., Błogosławieństwo wiary, Jedność, Kielce 2015.

21. Witko J., Moc błogosławieństw, "Przewodnik Katolicki” 52/2014. 